\title{
Short communication: Peptide profiling in cheeses packed using different technologies
}

\author{
Laura Sánchez-Rivera, Isidra Recio, Mercedes Ramos, and José Ángel Gómez-Ruiz ${ }^{1}$ \\ Instituto de Investigación en Ciencias de la Alimentación, Nicolás Cabrera, 9, 28049 Madrid, Spain
}

\begin{abstract}
Peptides released during the shelf life of cheeses packaged using 2 different technologies, vacuum packaging (VP) and modified-atmosphere packaging (MAP), were identified by on-line reverse phase-HPLC-tandem mass spectrometry. A total of 22 peptides from the N-terminal domain of $\alpha_{\mathrm{S}_{1}}$-casein $(\mathrm{CN})$ and 26 from $\beta$-CN were identified, the latter more evenly distributed over the whole sequence. Peptides were monitored during the shelf life of these cheeses when stored at $4^{\circ} \mathrm{C}$, revealing that the peptide profile changed significantly with the storage time. Qualitative differences between VP and MAP cheeses were only found for $3 \alpha_{\mathrm{S} 1}-\mathrm{CN}$ peptides, which were absent in MAP cheeses. Semiquantitative analysis of peptides revealed some differences between cheeses packaged using different technologies. However, evolution of peptides during storage followed a common trend in both types of cheeses. In addition, the presence of certain peptides, which had been previously described because of their potential bioactivity, is illustrated. For instance, some of the identified peptides had been previously reported as antihypertensive peptides, such as peptide $\alpha_{\mathrm{S1}}-\mathrm{CN}(1-9)$ or $\beta$-CN f(201-209).
\end{abstract}

Key words: cheese, vacuum packaging, modifiedatmosphere packaging, cheese bioactive peptide

\section{Short Communication}

Proteolysis is a phenomena occurring during cheese ripening comprised of numerous biochemical reactions that contribute to the flavor and texture of the final product. In the primary proteolysis, indigenous milk enzymes and those present in the coagulant play an important role. During secondary proteolysis, a great variety of peptides are released from the milk $\mathrm{CN}$ fraction by proteolytic enzymes which mainly belong to microorganisms that participate in cheese manufacturing (primary and secondary starters, as well as adventitious microflora; Fox, 1989).

Received October 23, 2012.

Accepted February 4, 2013.

${ }^{1}$ Corresponding author: joseangel.gomez.ruiz@csic.es
In recent decades, food packaging has undergone major technological development, partly in response to consumer demand for preservative-free food and in control-packaging methods to preserve quality and food safety. Changes in consumer preferences have affected buying habits and a growing interest in sliced and ready-to-eat products has been observed. These types of goods have a high value of convenience, but are also susceptible to physical and chemical changes. Vacuum packaging (VP) of cheese retards molds growth; however, the product may undergo changes in color, flavor, and texture (Romani et al., 2002) or show excessive surface humidity due to the migration of water from the inside to the surface (Pantaleão et al., 2007). Therefore, VP is not suitable for all kinds of cheeses, as it may lead to some structural and visual changes in the product. Consequently, alternative methods of packaging have been proposed, such as modified-atmosphere packaging (MAP). This technique appears suitable for cheese packaging, taking into account physicochemical and microbiological criteria (Dermiki et al., 2008), especially when using a gas mixture combination of $30 \%$ $\mathrm{CO}_{2}$ to $70 \% \mathrm{~N}_{2}$, which is able to extend the shelf life in terms of microbiological stability, keeping the sensory characteristics of Provolone cheese (Favati et al., 2007) or Greek whey cheese (Papaioannou et al., 2007) intact.

When cheese is packed to extend its shelf life, the effect of packaging on the ripening process should be evaluated. Some studies focused on the evaluation of proteolysis of VP cheese during ripening have been carried out using total nitrogen and ripening index (Tarakci and Kucukoner, 2006). The application of reverse phase-HPLC analysis (Sousa et al., 2001; Poveda et al., 2003) or HPLC-tandem mass spectrometry (HPLCMS/MS; Piraino et al., 2007) has been proposed as a reliable tool to evaluate proteolysis in cheese. However, to our knowledge no comparative studies have been carried out on peptide profile changes occurring along the shelf life of cheese subjected to different packaging techniques.

In this study, HPLC-MS/MS detection has been used to identify the peptides released and evaluate the peptidic profile changes during the shelf life of cheeses packaged using 2 different technologies. Based on previ- 
ous studies, the presence, origin, and potential bioactivities of these peptidic sequences are also discussed.

Semihard cheeses samples, provided by a national dairy manufacturer, were made out of mixed pasteurized sheep, cow, and goat milk with 2 different packaging systems (VP for cheese wedges and MAP for sliced cheeses). Prior to cheese packaging, the curd was processed using different molds, depending on the final format, and subsequently ripened for $20 \mathrm{~d}$ under controlled temperature and humidity conditions

Cheese samples were received immediately after manufacturing and stored at $4^{\circ} \mathrm{C}$ for the duration of the study: $0,30,60$, and $90 \mathrm{~d}$ for the MAP samples, and $0,30,60,90$, and $150 \mathrm{~d}$ for the VP samples. In both cases the maximum number of storage days refers to the shelf-life of the respective cheese type.

Water-soluble extracts were obtained at each selected time according to the method described by Gómez-Ruiz et al. (2002). Supernatants were ultrafiltered on a 3,000 Da cut-off ultrafiltration membrane (Pall Corporation, Ann Arbor, MI). The 3,000 Da permeates were freezedried and kept at $-20^{\circ} \mathrm{C}$ until their analysis.

Reverse phase-HPLC-MS/MS analyses of the permeates $<3,000$ Da were carried out on an Agilent HPLC system (Agilent Technologies, Waldbronn, Germany) connected on line to an Esquire-LC quadrupole ion trap instrument (Bruker Daltonik $\mathrm{GmbH}$, Bremen, Germany). A Mediterranea Sea18 $15 \times 0.21 \mathrm{~cm}$ column was used in the experiments (Teknokroma, Barcelona, Spain). Auto MS(n) analyses used a signal threshold of 10,000 , a voltage ramp from 0.35 to $1.4 \mathrm{~V}$ for the fragmentation of precursor ions, and an isolation width of $4.0 \mathrm{~m} / \mathrm{z}$. The estimated amount of peptides (in arbitrary units) in each sample was calculated by extracting their corresponding characteristic ions (molecular ion or doubly charged ion, when present); duplicate samples were prepared for each time and package condition, and were individually analyzed.

The peptide profile of the different cheeses was studied by evaluating both the UV spectra and the mass spectra after analysis by liquid chromatography. Essentially no differences in the UV spectra were found between the 2 types of packaging along the storage times (results not shown). A more detailed MS analysis revealed some differences in the peptide profile of cheeses packaged with both systems. A total of 48 peptides were identified, 22 sequences belonging to $\alpha_{\mathrm{S1}}$-CN and 26 sequences to $\beta$-CN. No peptides were detected from $\alpha_{\mathrm{s}^{2}}$ CN or $\kappa-\mathrm{CN}$. This can be linked to their lower content compared with $\alpha_{\mathrm{S1}^{-}}$or $\beta$-CN. In addition, the fragment incorporated to the curd derived from $\kappa-\mathrm{CN}$, para- $\kappa-\mathrm{CN}$, has been described to be rather resistant to proteolysis. As cheeses were manufactured with different types of milk some of the sequences could belong to different species (cow, goat, or sheep). Figure 1 shows the $\alpha_{\mathrm{S} 1}$-CN-derived peptides identified in VP and MAP cheeses, their presence during the storage time, and their intensity obtained from the HPLC-MS analysis at $0 \mathrm{~d}$ of MAP cheese. Most of the identified peptides from $\alpha_{S_{1}}-\mathrm{CN}$ were released from the N-terminal segment. The peptides that showed the highest intensities at $0 \mathrm{~d}$ corresponded to $\alpha_{\mathrm{S1}} \mathrm{CN} \mathrm{f}(1-16), \mathrm{f}(17-23)$, and $\mathrm{f}(24-32)$, although many other peptides that also belong to these 3 regions were identified. In cheese, chymosin rapidly cleaves at $\mathrm{Phe}_{23}-\mathrm{Phe}_{24}$ in cow milk and $\mathrm{Phe}_{23^{-}}$ $\mathrm{Val}_{24}$ in sheep and goat milk, giving 2 major fragments as a result: $\alpha_{\mathrm{S} 1}-\mathrm{CN} \mathrm{f}(1-23)$ and $\mathrm{f}(24-199)$ (McSweeney and Fox, 1993). Further hydrolysis by cell envelopeassociated proteinases and endopeptidases of starter and nonstarter bacteria release several peptides from

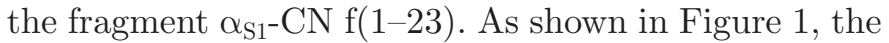
same sequences were identified regardless the packaging method used; the only exceptions were the $\alpha_{S_{1}}-C N$ peptides RPKHPIK, LPQEVLN, and PFPEVF, which were absent in MAP cheeses. Additional differences between the 2 packaging methods were also notable at the quantitative level. For example, the evolution of some of the most abundant $\alpha_{S_{1}}-\mathrm{CN}$ peptides during the storage time in VP and MAP cheeses is shown in Figure 2. In some cases, higher peptide intensities during storage time were detected in VP cheeses compared with MAP cheeses, especially at longer storage times (90 d). This is the case of the peptides $\alpha_{\mathrm{S} 1}-\mathrm{CN} \mathrm{f}(24-32)$ and $\alpha_{\mathrm{S}^{-}} \mathrm{CN}$ $\mathrm{f}(25-32$; Figure 2). However, some peptides reached higher concentration in MAP cheeses compared with VP cheeses, as can be observed for the peptide $\alpha_{S_{1}-} \mathrm{CN}$ $\mathrm{f}(1-16)$. Concerning their evolution during the storage time, some peptides $\left[\alpha_{\mathrm{S}^{-}} \mathrm{CN} \mathrm{f}(17-23), \alpha_{\mathrm{S} 1}-\mathrm{CN} f(24-32)\right.$, and $\left.\alpha_{\mathrm{S}^{-}} \mathrm{CN} f(25-32)\right]$ behaved similarly regardless the packaging technology, whereas others followed different patterns $\left[\alpha_{\mathrm{S} 1}-\mathrm{CN} \mathrm{f}(1-9)\right.$ and $\left.\alpha_{\mathrm{S} 1}-\mathrm{CN} f(17-22)\right]$.

In contrast to $\alpha_{S_{1}}-\mathrm{CN}$, peptides from $\beta$-CN were more evenly identified over the whole sequence. For $\beta-\mathrm{CN}$ peptides, no qualitative differences were found between VP and MAP cheeses (Figure 3). Those peptides that reached the highest concentrations in the water-soluble extract corresponded to $\beta-\mathrm{CN} \mathrm{f}(1-6), \mathrm{f}(44-52), \mathrm{f}(45-52)$, and $\mathrm{f}(47-52$; Figure 4$)$. It is notable that, in general, for $\beta$-CN peptides differences were more pronounced at longer storage times (90 d) and peptide evolution during storage was similar for both packaging techniques. At 90 $\mathrm{d}$, peptides $\beta$-CN $\mathrm{f}(7-14)$ and $\mathrm{f}(44-52)$ reached higher levels in VP cheeses than MAP cheeses, but the opposite was found for $\beta-\mathrm{CN} \mathrm{f}(46-52), \mathrm{f}(47-52)$, and $\mathrm{f}(74-82)$.

Some of the peptides identified in the water-soluble extracts of these cheeses have been previously described because of their potential to exert biological activities. For instance, $\alpha_{\mathrm{S} 1}-\mathrm{CN}$ f(1-9) with sequence 


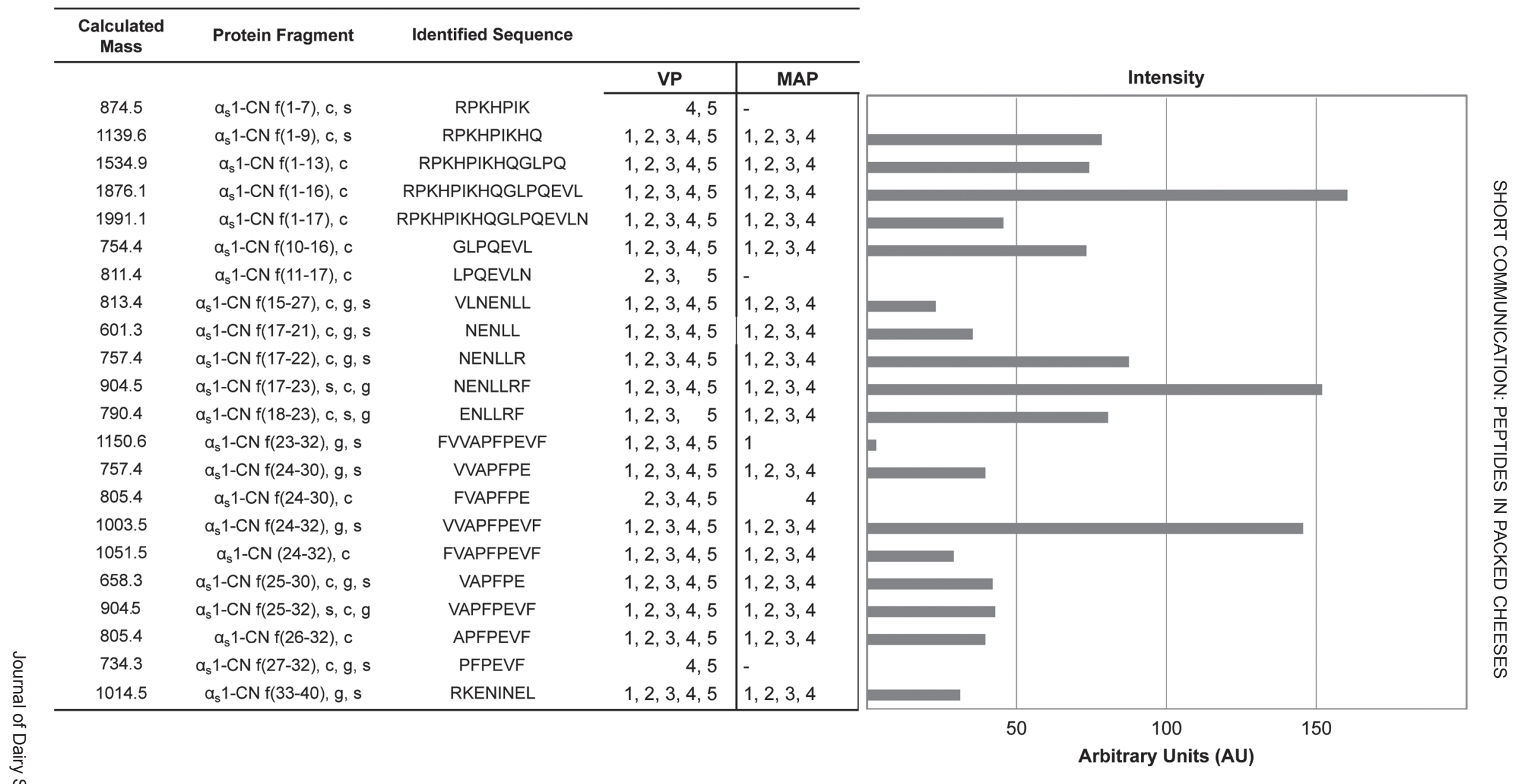
were identified by HPLC-tandem mass spectrometry analysis, and the intensity of the peptides of MAP cheeses at $0 \mathrm{~d}$ is represented on the right (value $\times 10^{7}$ units). Protein fragments come from cow (c), sheep (s), and goat (g) milk. The first column of the table indicates calculated monoisotopic mass, and the numbers for VP and MAP indicate the presence of peptides at $0(1), 30(2), 60(3), 90$ (4), and 150 (5) d. 

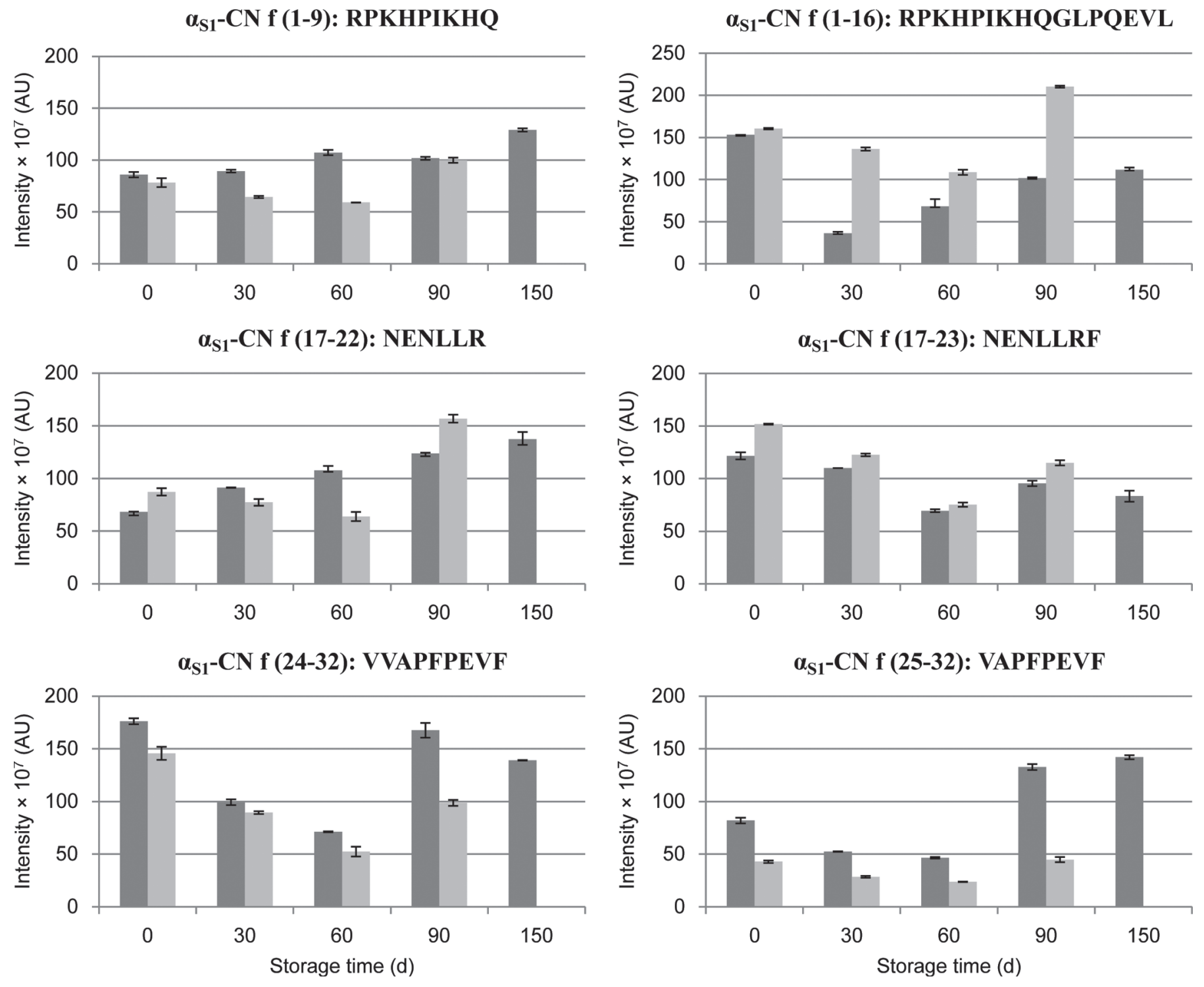

Figure 2. Relative amount of $\alpha_{\mathrm{S}^{-}} \mathrm{CN}$-derived peptides found in the 3,000 Da permeate from the water-soluble extracts of vacuum-packaged (dark gray bars) and modified-atmosphere-packaged (light gray bars) cheeses stored at $4^{\circ} \mathrm{C}$ during their shelf life (150 and $90 \mathrm{~d}$, respectively). Amount of peptide is expressed as intensity (arbitrary units) of the signal obtained from the HPLC-tandem mass spectrometry analysis. Each value corresponds to the average of a duplicate sample.

RPKHPIKHQ had been identified and isolated in other cheeses, such as 8 mo-ripened Gouda cheese (Saito et al., 2000), Festivo cheese (Ryhänen et al., 2001), and Scandinavian cheeses (Lund and Ardö, 2004). A potent angiotensin-converting enzyme (ACE)-inhibitory activity had been reported for this peptide $\left(\mathrm{IC}_{50}=13.4 \mu M\right)$, although it showed weak antihypertensive activity in rats (Saito et al., 2000). Similarly, other peptides that possess ACE-inhibitory activity are $\alpha_{\mathrm{S1} 1} \mathrm{CN} \mathrm{f}(18-23)$, ENLLRF, with $\mathrm{IC}_{50}=82.4 \pm 9 \mu M$ (Quirós et al., 2005), and $\alpha_{\mathrm{S}_{1}} \mathrm{CN} f(25-32)$, VAPFPEVF, which shows moderate ACE-inhibitory activity (Contreras et al., 2009). Another related identified fragment was the peptide
$\alpha_{\mathrm{S} 1}-\mathrm{CN}$ f(24-32), FVAPFPEVEF, which had been reported with both antimicrobial activity (Rizzello et al., 2005) and ACE-inhibitory activity (Ong et al., 2007). A decapeptide derived from the $\alpha_{\mathrm{S}^{-}} \mathrm{CN}$ N-terminal region, $\alpha_{\mathrm{S} 1}-\mathrm{CN} \mathrm{f}(3-13)$, has demonstrated antioxidant activity and stimulatory activity of adiponectin secretion in adipose cell culture (Higurashi et al., 2007). It has to be highlighted that this sequence is included in several of the most abundant peptides in Figure 1.

One of the most abundant peptides, $\beta-\mathrm{CN} f(1-6)$, RELEEL, had been previously identified in fermented milk produced by Lactobacillus helveticus CP790, showing moderate ACE-inhibitory and antihypertensive 


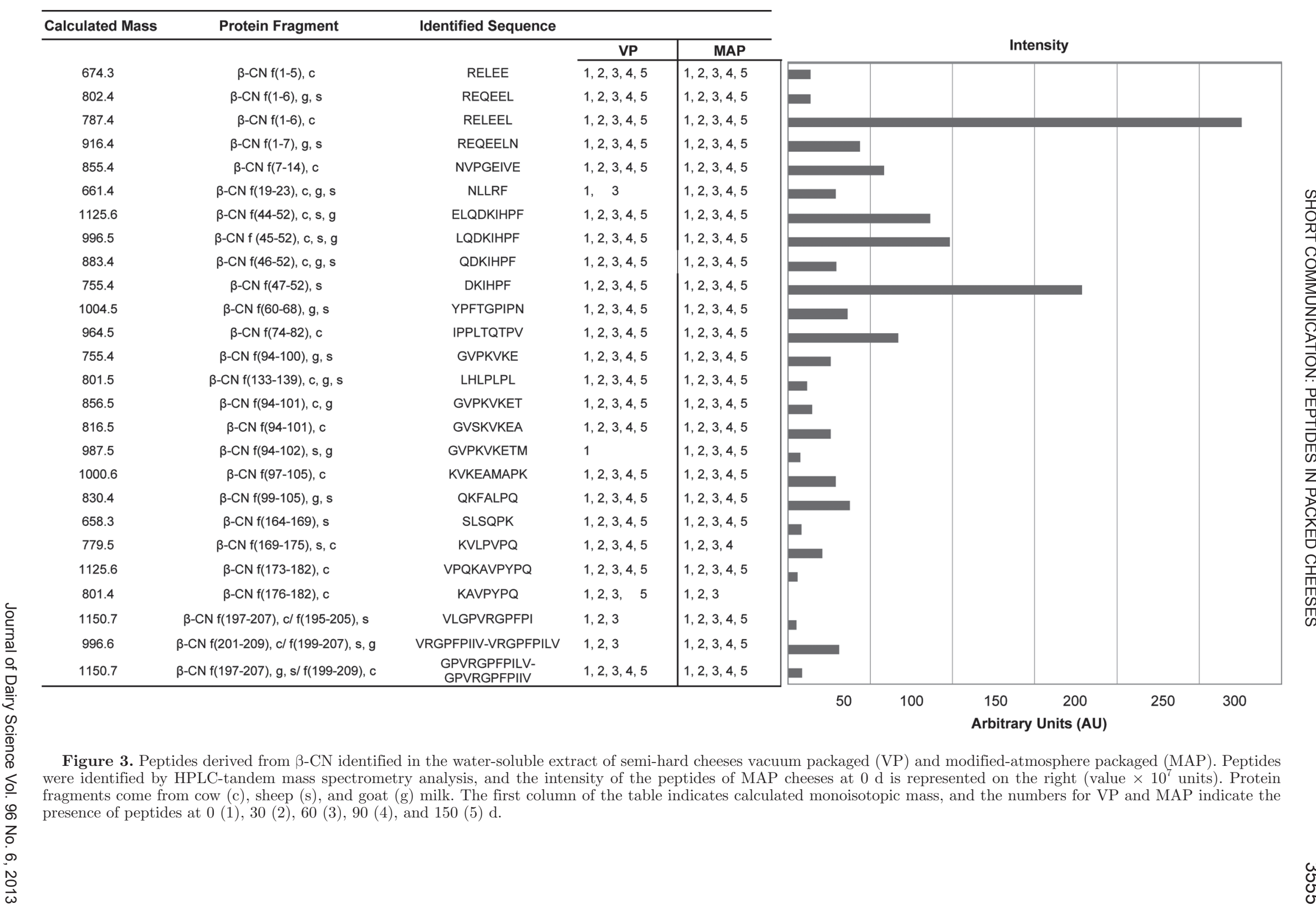


$\beta-C N$ f(44-52): ELQDKIHPF

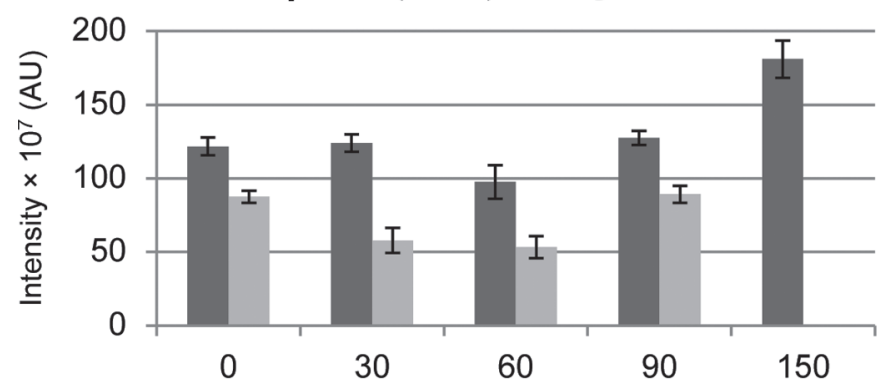

B-CN f(74-82): IPPLTQTPV

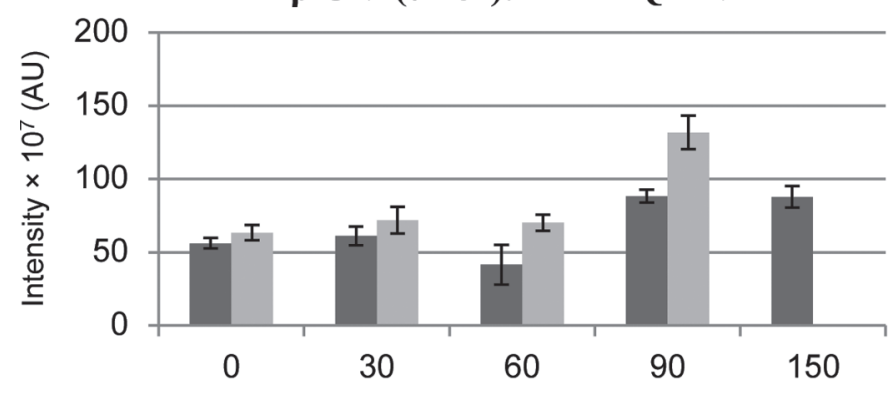

B-CN f(47-52): DKIHPF

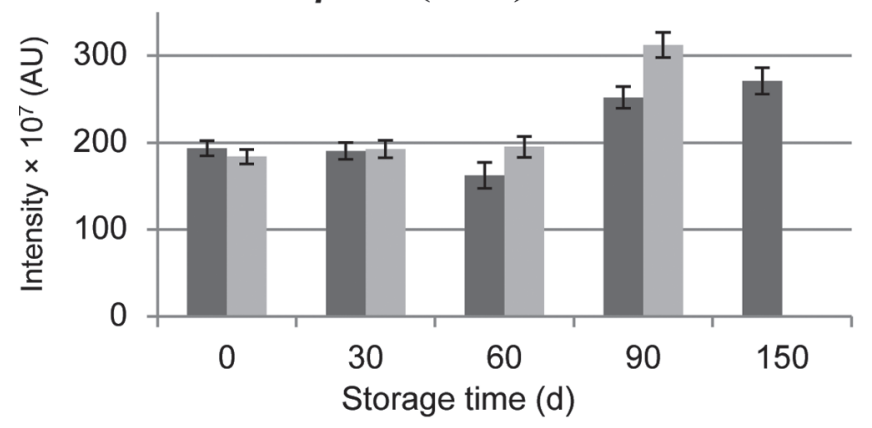

B-CN f(1-6): RELEEL

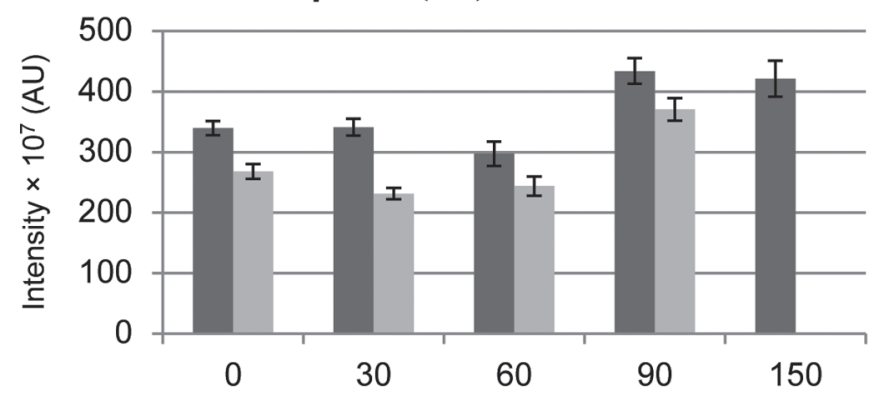

$\beta-C N$ f(7-14): NVPGEIVE
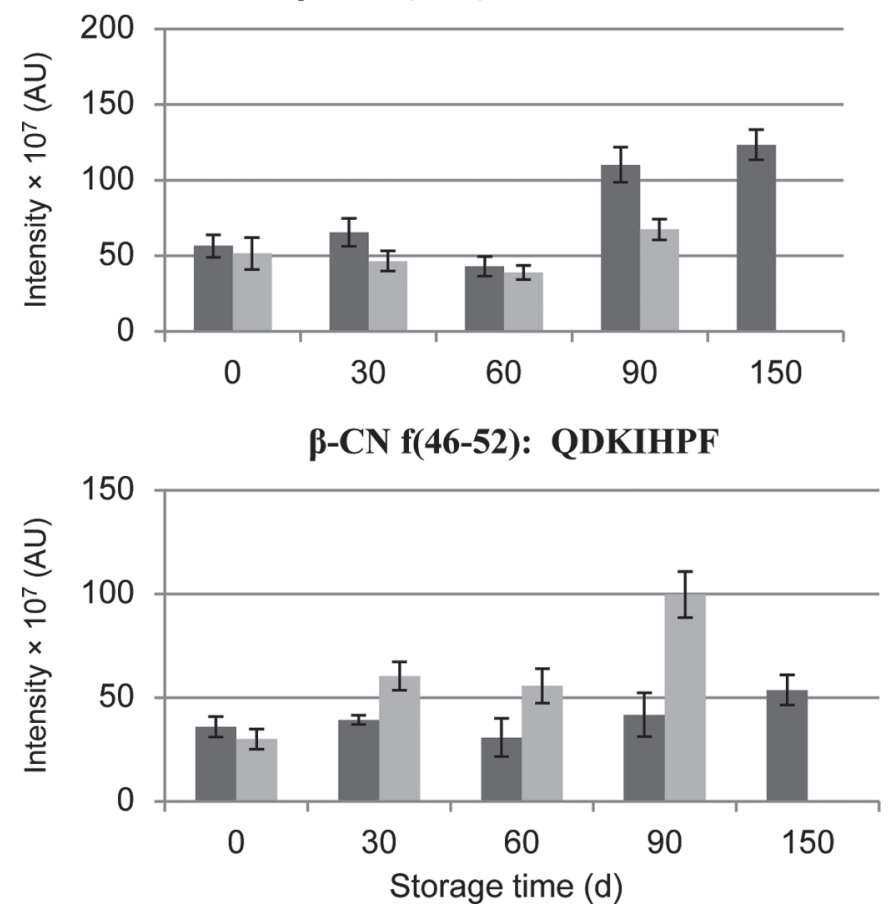

Figure 4. Relative amount of $\beta$-CN-derived peptides found in the 3,000 Da permeate from the water-soluble extracts of vacuum-packaged (dark gray bars) and modified-atmosphere-packaged (light gray bars) cheeses stored at $4^{\circ} \mathrm{C}$ during their shelf life (150 and $90 \mathrm{~d}$, respectively). Amount of peptide is expressed as intensity (arbitrary units) of the signal obtained from the HPLC-tandem mass spectrometry analysis. Each value corresponds to the average of a duplicate sample.

activity (Maeno et al., 1996). Specifically important in terms of bioactivity is the presence of the $\beta$ - $\mathrm{CN}$ peptide LHLPLPL [f(133-139)], a well-conserved sequence in many species. Although this peptide shows only moderate ACE-inhibitory activity $\left(\mathrm{IC}_{50}=432.7 \mu \mathrm{M}\right.$; Miguel et al., 2006), it can be a precursor of the potent antihypertensive peptide LHLPLP (Quirós et al., 2007). Likewise, the peptide with sequence YPFTGPIPN [ $\beta$ $\mathrm{CN} \mathrm{f}(60-68)]$ showed a potent ACE-inhibitory activity $\left(\mathrm{IC}_{50}=14.8 \mu M\right)$ (Saito et al., 2000), and was isolated in Manchego cheese (Gómez-Ruiz et al., 2004). Other identified peptides from $\beta$-CN reported as moderate ACE-inhibitors are $\beta$-CN f(69-75) with sequence $\mathrm{KV}$ LPVPQ (although with significant antihypertensive ac- tivity in rats; Maeno et al., 1996) and peptide DKIHPF [f(47-52)], identified in several Spanish cheeses (GómezRuiz et al., 2004, 2006). Likewise, peptide VRGPFPIIV [3-CN f(201-209)] showed a significant effect on the reduction of blood pressure in rats despite possessing only moderate ACE-inhibitory activity (Miguel et al., 2006).

In summary, 48 peptides were identified in the watersoluble extracts of VP and MAP cheeses. It has been described that product composition, processing, storage conditions (time and temperature), and packaging contribute to the residual cheese-ripening processes observed during storage. The influence of 2 factors, storage time and packaging, were evaluated in this 
study. During storage time at $4^{\circ} \mathrm{C}$ it was observed that the peptide profile changed under both packaging technologies. The variation mainly referred to the relative amount of the different peptides, as most of the peptidic sequences identified were the same regardless of packaging technique and storage time. Some exceptions were the $\alpha_{S^{1}}$ CN peptides $\mathrm{f}(1-7), \mathrm{f}(11-17)$, and $\mathrm{f}(27-32)$ that were only identified in VP cheeses. In contrast, the same $\beta$-CN peptides were identified in VP and MP cheeses. Comparing both packaging systems, a nonconstant pattern was observed concerning the relative amounts of peptides during the storage time. Looking at the longest common storage time $(90 \mathrm{~d})$, peptides such as $\alpha_{\mathrm{S}^{-}} \mathrm{CN} \mathrm{f}(24-32), \mathrm{f}(25-32)$, and $\beta-\mathrm{CN}(44-52)$ reached higher relative levels in VP cheeses compared with MAP cheeses, whereas the opposite was observed for other peptides $\left[\alpha_{\mathrm{S}_{1}} \mathrm{CN} \mathrm{f}(1-16), \beta-\mathrm{CN} \mathrm{f}(46-52-32)\right.$, and $\beta-\mathrm{CN}(74-82)]$. In addition, though all $\beta-\mathrm{CN}$ peptides showed a similar trend during storage time in both types of cheeses, the behavior of $\alpha_{\mathrm{S1}^{-}} \mathrm{CN}$ peptides in $\mathrm{VP}$ and MP cheeses varied depending on their sequence. The identification of these minor differences between VP and MAP cheeses merits further research to better understand their correlation with the organoleptic properties of cheeses packaged with different technologies. Among the identified peptides, several of them have been described as bioactive sequences showing different bioactivities. These bioactivities should be also further evaluated using in vivo studies to corroborate the potential of these cheeses.

\section{ACKNOWLEDGMENTS}

This work was supported by projects CENIT Pronaos AGL2011-24643 and Consolider-Ingenio FUN-CFood CSD 2007-063 from Ministerio de Economía y Competitividad (Madrid, Spain). Laura Sánchez-Rivera acknowledges Consejo Superior de Investigaciones Científicas (CSIC) for a Junta para la Ampliación de Estudios (JAE) Program fellowship.

\section{REFERENCES}

Contreras, M., R. Carrón, M. J. Montero, M. Ramos, and I. Recio. 2009. Novel casein-derived peptides with antihypertensive activity. Int. Dairy J. 19:566-573.

Dermiki, M., A. Ntzimani, A. Badeka, I. N. Savvaidis, and M. G. Kontominas. 2008. Shelf-life and quality attributes of the whey cheese "Myzithra Kalathaki" using modified atmosphere packaging. Food Sci. Technol-LEB. 41:284-294.

Favati, F., F. Galgano, and A. M. Pace. 2007. Shelf-life evaluation of portioned Provolone cheese packaged in protective atmosphere. Food Sci. Technol-LEB. 40:480-488.

Fox, P. F. 1989. Proteolysis during cheese manufacture and ripening. J. Dairy Sci. 72:1379-1400.

Gómez-Ruiz, J. A., M. Ramos, and I. Recio. 2002. Angiotensin-converting enzyme-inhibitory peptides in Manchego cheeses manufactured with different starter cultures. Int. Dairy J. 12:697-706.
Gómez-Ruiz, J. A., M. Ramos, and I. Recio. 2004. Identification and formation of angiotensin-converting enzyme-inhibitory peptides in Manchego cheese by high-performance liquid chromatographytandem mass spectrometry. J. Chromatogr. A 1054:269-277.

Gómez-Ruiz, J. A., G. Taborda, L. Amigo, I. Recio, and M. Ramos. 2006. Identification of ACE-inhibitory peptides in different Spanish cheeses by tandem mass spectrometry. Eur. Food Res. Technol. 223:595-601.

Higurashi, S., Y. Kunieda, H. Matsuyama, and H. Kawakami. 2007. Effect of cheese consumption on the acumulation of abdominal adipose and decrease in serum adiponectin levels in rats fed a calorie dense diet. Int. Dairy J. 17:1224-1231.

Lund, M., and Y. Ardö. 2004. Purification and identification of water-soluble phosphopeptides from cheese using $\mathrm{Fe}(\mathrm{III})$ affinity chromatography and mass spectrometry. J. Agric. Food Chem. 52:6616-6622

Maeno, M., N. Yamamoto, and T. Takano. 1996. Identification of an antihypertensive peptide from casein hydrolysates produced by a proteinase from Lactobacillus helveticus CP790. J. Dairy Sci. 79:1316-1321.

McSweeney, P. L., N. F. Olson, P. F. Fox, A. Healy, and P. Højrup. 1993. Proteolytic specificity of chymosin on bovine alpha s1-casein. J. Dairy Res. 60:401-412.

Miguel, M., I. Recio, M. Ramos, M. A. Delgado, and M. A. Aleixandre. 2006. Antihypertensive effect of peptides obtained from Enterococcus faecalis-fermented milk in rats. J. Dairy Sci. 89:3352-3359.

Ong, L., A. Henriksson, and N. P. Shah. 2007. Angiotensin converting enzyme-inhibitory activity in Cheddar cheeses made with the addition of probiotic Lactobacillus casei $\mathrm{sp}$. Lait 87:149-165.

Pantaleão, I., M. M. E. Pintado, and M. F. F. Poças. 2007. Evaluation of two packaging systems for regional cheese. Food Chem. 102:481-487.

Papaioannou, G., I. Chouliara, A. E. Karatapanis, M. G. Kontominas, and I. N. Savvaidis. 2007. Shelf-life of a Greek whey cheese under modified atmosphere packaging. Int. Dairy J. 17:358-364.

Piraino, P., V. K. Upadhyay, R. Rossano, P. Riccio, E. Parente, A. L. Kelly, and L. H. McSweeney. 2007. Use of mass spectrometry to characterize proteolysis in cheese. Food Chem. 101:964-972.

Poveda, J. M., M. J. Sousa, L. Cabezas, and P. L. H. McSweeney. 2003. Preliminary observations on proteolysis in Manchego cheese made with a defined-strain starter cultura and adjunct starter (Lactobacillus plantarum) or commercial starter. Int. Dairy J. 13:169-178.

Quirós, A., B. Hernández-Ledesma, M. Ramos, L. Amigo, and I. Recio. 2005. Angiotensin-converting enzyme inhibitory activity of peptides derived from caprine kefir. J. Dairy Sci. 88:3480-3487.

Quirós, A., M. Ramos, B. Muguerza, M. A. Delgado, M. Miguel, A. Aleixandre, and I. Recio. 2007. Identification of novel antihypertensive peptides in milk fermented with Enterococus faecalis. Int. Dairy J. 17:33-41.

Rizzello, C. G., I. Losito, M. Gobbetti, T. Carbonara, M. D. De Bari, and G. Zambonin. 2005. Antibacterial activities of peptides from the water-soluble extracts of Italian cheese varieties. J. Dairy Sci. 88:2348-2360.

Romani, S., G. Sacchetti, P. Pittia, G. G. Pinnavaia, and M. Dalla Rosa. 2002. Physical, chemical, textural and sensorial changes of portioned Parmigiano Reggiano cheese packed under different conditions. Food Sci. Technol. Int. 8:203-211.

Ryhänen, E. L., A. Pihlanto-Leppälä, and E. Pahkala. 2001. A new type of ripened, low-fat cheese with bioactive properties. Int. Dairy J. 11:441-447.

Saito, T., T. Nakamura, H. Kitazawa, Y. Kawai, and T. Itoh. 2000. Isolation and structural analysis of antihypertensive peptides that exist naturally in Gouda cheese. J. Dairy Sci. 83:1434-1440.

Sousa, M. J., Y. Ardö, and P. L. H. McSweeney. 2001. Advances in the study of proteolysis during cheese ripening. Int. Dairy J. $11: 327-345$

Tarakci, Z., and E. Kucukoner. 2006. Changes on physicochemical, lipolysis and proteolysis of vacuum-packed Turkish Kashar cheese during ripening. J. Central Europ. Agric. 7:459-464. 